\title{
A POTENCIÁLIS VÁROSOK KÖRNYEZETI ÁLLAPOTÁNAK ÉRTÉKELÉSE, MINŐSÍTÉSE
}

\author{
(The evaluation and qualification of the state of environment in some \\ potential towns)
}

\section{OLÁH FERENC}

\section{Elôzmények, kutatási cél}

Egy átfogó kutatás, vizsgálat keretében - előzetesen kijelölt - 177 település környezeti állapotának felmérését, az összehasonlíthatóság követelménye miatt számszerủsített módon való értékelését, minősítését, valamint csoportosítását kellett elvégezni.

Az egészséges környezet az ember életminőségének alapvető tényezője (NKTK, 1994). $\mathrm{E}$ szempontra alapozva a vizsgálat célja a kiválasztott településeken élö lakosság számára nyújtott környezeti feltételek kedvező, kevésbé kedvező voltának feltárása volt.

A hazai igények, kutatások, az ENSZ, az OECD és az Európa Tanács konvenciói, ajánlásai alapján 1994-ben elkészült a Nemzeti Környezet- és Természetpolitikai Koncepció. Erre alapozva még ugyanezen évben megjelent a korábbi "A környezet állapota és védelme" c. KSH. kiadvány korszerúbb változata "Hazánk környezeti állapotának mutatói" címmel. A folyamatot 1995. májusában az "1995. évi LIII. törvény a környezet védelmének általános szabályairól" c. elöterjesztés Országgyúlés általi elfogadása, törvényerőre emelése zárta.

\section{Módszer}

Vizsgálatunkban négy - egyenként is összetett - szempont alapján végeztük el a települések aktuális környezeti állapotának felmérését, értékelését. Szempontonként különbözó jellegü - statisztikai és/vagy kartográfiai - adatbázist használtunk, az értékelést - alább részletezett módon - pontozásos rendszerben végeztük.

A vizsgálatban felhasznált adatsorok - általában - még nem elsődlegesen a környezeti állapot-felmérések szempontjai alapján vannak összegyújtve. Az adatok hiánya, nehéz összevethetősége azonban már nem olyan mértékü, hogy körultekintó értékeléssel homályban maradnának a környezet állapotát befolyásoló fó folyamatok, és alapvető tévedések terhelnék a tájegységek, térségek állapotának megítélését (HKÁM 1994).

A kép finomítása, az állapotok és állapotváltozások részletesebb megismerése érdekében elengedhetetlen, hogy minél elóbb megvalósuljon a környezeti állapotjellemzés és értékelés egységes, és az európai gyakorlattal harmonizáló rendszere.

$\mathrm{Ez}$ - számos más terület mellett - a regionális kutatás és tervezés fejlődése, a terület- és településfejlesztés hatékony müködése érdekében sem nélkülözhető.

A KTM már 1993-ban rögzítette a környezet állapotára vonatkozó jelentések tartalmát, figyelemmel az OECD-országok paraméter-rendszerére, amely biztosítani hivatott a környezeti állapotok összehasonlíthatóságát. 
Jelen munkánkban a fenti összeállításból az általunk, s a kitüzött cél elérése érdekében legfontosabbnak tekintett mutatók rendszereit választottuk ki, s alkalmaztuk.

\section{Természeti környezeti mutató}

Kiemelten fontos minősítési szempont, hiszen "... az ország természeti környezete nemzeti örökségünk, pótolhatatlan és megismételhetetlen értékek hordozója" (NKTK 1994). Ez a mutató négy részterület pontszámaiból tevődik össze:

\section{Erdösültség}

Az egészséges környezethez alapvetően fontos a települések lakott- és közigazgatási területén lévő zöldterületek és erdők minél jelentősebb részaránya. Az elérhetỏ statisztikai forrásokban csak a városok zöldterületeinek adatai szerepelnek, a vizsgálatunkba bevont nem városi jogállású településeké nem, így csak az erdỏsültség mértékével számoltunk.

Ennek megfelelően alakult az adható pontszám is, azaz:

- a település közigazgatási területéből az erdỏvel borított terület megközelítő részaránya $0-5$ pont

\section{Felszíni vizek}

Egy település környezeti állapotának megítélését elönyösen befolyásolhatja (településkép, optimális légnedvesség, levegôtisztaság, vízbázis), ha megfelelő tisztaságú élővízzel (patak, folyó, tó) rendelkezik, s ronthatja, ha az erösen szennyezett:

- a településen, kozigazgatási területén milyen vízminőségi osztályba tartozó felszíni víz található 0-10 pont

\section{Felszín alatti vízminőség védelmi területek}

Ezek akár karsztterületen, akár porózus, törmelékes üledékes kózetủ területen találhatók, felszíni szennyezỏdésre kiemelten érzékenyek. Lévén kivétel nélkül - jelenleg és távlatokban is - regionális jelentőségủ ivóvízbázisok, szerepeltetésük az értékelési rendszerben különösen fontos. A felszíni vízminőség védelmi területek ugyan szintén az érzékeny kategóriába tartoznak, viszont regionális jelentőségúk kisebb, s az innen kiemelt víz döntỏen öntözésre, $\mathrm{s}$ csak kisebb hányada szolgál ivóvíz biztosítására:

-a település közigazgatási területe milyen arányban fed le kiemelt vízminőség-védelmi területet $\quad 0-5$ pont

\section{Védett természeti értékek}

A védett területek természeti környezeti állapotát elvileg optimálisnak kell tekinteni. Azonban más-más tevékenységi körök megengedettek, így más-más folyamatok, hatások jelentkeznek a különböző védettségi szintbe sorolt területeken. Minél magasabb fokú a természetvédelmi oltalom, annál kőzelebb állhat az aktuális természeti környezeti állapot az elméleti optimális szinthez:

- a település területén milyen védertségi fokozatba sorolt védett természeti érték található $\quad 0-10$ pont

\section{Infrastrukturális környezeti mutató}

A természeti környezeti sajátosságok mellett a települések infrastrukturális ellátottsága is hasonló jelentőséggel bír az értékelési rendszerben. 


\section{Közmũvesitettség}

A lakosság életminőségét alapvetően meghatározza, hogy milyen kommunális infrastrukturális helyzet jellemző a településen. Ennek értékelésére szolgál a három részmutató, amelyek mindegyike a közüzemi vízszolgáltatás és -csatornázottság adatain nyugszik:

$\begin{array}{ll}\text { - a közüzemi vízhálózatba bekotott lakások a település lakásszáma százalékában } & 0-10 \text { pont } \\ \text { - a közcsatoma-hálózatra rákapcsolt lakások a telepủlés lakásszáma százalékában } & 0-10 \text { pont } \\ \text { - a kózcsatoma hálózat hossza a kozilzemi vízhálózat hosszának százalékában } & 0-10 \text { pont }\end{array}$

\section{Hulladékelhelyezés a település területén}

Speciális települési környezeti gond a keletkezỏ kommunális, mezőgazdasági, ipari hulladékok összegyưjjtése, tárolása, kezelése. Nagyon jelentös különbségek származnak abból, hogy szervezett-, rendezett-e a kủlönböző típusú hulladékok gyüjtése, tárolása. Természetesen szintén különbséget kell tenni aszerint is, hogy a létesített lerakó felszíni szennyeződés, érzékenység szempontjából milyen típusú, kőzetminőségü területen található:

- ha rendelkezik kommunális hulladéklerakóval;

a felszíni szennyezódés-érzékenység szempontjából milyen kategóriájú teruleten találhatóható 0-6 pont

- ha területén mezógazdasági és/vagy ipari hulladéklerakó található;

a felszíni szennyezödés érzékenység szempontjából milyen kategóriajú területen található 0-6 pont

- az ipari és/vagy mezógazdasági veszélyeshulladék-lerakat felszíni szennyeződés érzékenység szemponțából

milyen kategóriájú területen található (ha nincs veszélyes-hulladék lerakat: 5 pont) $\quad 0-5$ pont

\section{Levegőminőségi mutató}

A telepulési környezeti állapotfelmérés fontos eleme a levegőminőség meghatározása. A települések levegőjét elsősorban a közlekedésből, valamint a fütési idényben a háztartásokból származó égéstermékek és por szennyezi. Ilyen tartalmú településsoros adatok természetesen - a mérés hiánya miatt - nincsenek. A levegőminőségi mutató meghatározásánál ezért alkalmaztam az alábbi számitási, értékelési módszert:

- a vezetékes gázszolgáltatásba bekapcsolt lakások aránya

- a telepulésen átvezetó kőzút kategóriajja alapján

- ha a telepulésen crőteljes por, fústkibocsátással járó iparág található:

$0-10$ pont

$0-8$ pont

-2 pont

A négy vizsgálati szempont alapján legkedvezóbb környezeti állapotú telepulés maximum 95 pontot kaphatna.

\section{Eredmények}

A részpontszámok összesítése után kialakult egy sorrend a vizsgált települések között ( $I$. $a ́ b r a)$. A legalacsonyabb pontérték - 18 pont - és a legmagasabb - 69 pont - egy-egy településen jellemzỏ érték. Ezen szélsőértékek közelébe szintén csak néhány település került. A többség - 138 település - a 26-50 pont közötti intervallumban található. A 177 vizsgált település kategorizálását az alábbi módon végeztem el, alkalmazkodva az egyik kiindulási feltételhez, amely szerint 5 - lehetỏleg megközelítően azonos számú elemet tartalmazó - csoportba kell óket besorolni (2. ábra). 
Az első csoportba a legkedvezőbb környezeti állapottal jellemezhető 29 település került, 69 és 51 pont közötti összesitett értékkel. Területi elhelyezkedésüket vizsgálva kitűnik, hogy egynegyedük a budapesti agglomeráció részét képezi, ezen belul is többségük a budai oldalon található. Összességében jellemző, hogy többségüknél mind a négy értékelési szempont alapján az átlagnál több ponttal rendelkeznek (2.ábra). Kivétel nélkül magas pontértéket kaptak az infrastrukturális közmüellátottság alapján. Néhảny település kivételével a legkevesebb pontot a hulladékelhelyezés, -kezelés révén kapták, $\mathrm{s}$ ez jelzi az egyébként országosan is egyik legsúlyosabb problémát a települési környezetek vonatkozásában. Szintén koncentráltabb a Duna-menti agglomerációs sávban és a Balaton környékén a kedvezőbb környezeti állapotú települések előfordulása.

$\mathrm{Az}$ elöbbi térségben lévő négy település közös sajátossága, hogy szintén a hulladékelhelyezés, -kezelés, valamint a levegőminőség alapján az átlag alatti pontértékkel bírnak (2. ábra). Ez azért figyelemreméltó, mert többféle szempontból is kiemelt térségben - a Dunakanyar, az Almás-Táti-Duna-völgy területén - találhatók, s ez a negatív sajátosságuk hosszabb távon csökkentheti $\mathrm{pl}$. az idegenforgalmi vonzerejüket is. Szembetủnő még, hogy az Észak-magyarországi-Középhegység területén - jelentősebb iparral vagy múlttal rendelkezö - öt település került az első kategóriába. Kifejezetten alföldi település kettő szerepel ebben a csoportban.

A második csoportba tartozik 43 település, 41-50 pont közötti összesített értékekkel. A települések több, mint harmada itt is koncentráltan - az agglomerációban $\mathrm{s}$ annak közvetlen szomszédságában, vonzásában - található (2. ábra). Figyelmet érdemel még a Kisalföld északnyugati része, valamint a Közép-Tiszántúl területe. Természeti környezeti állapotuk nem rosszabb, mint az elsỏ csoportba tartozó településeké, viszont szélesebb skálán helyezkednek el, nagyobb a differencia. Hulladékelhelyezés és levegőminőség tekintetében nincs számottevő különbség a két csoport települései között. Második csoportba kerülésuket elsősorban a közmüvesitettségi mutató átlagosan alacsonyabb pontértékei indokolják.

A harmadik kategória 32 települése 36-40 pont közötti értékkel rendelkezik. Ebben a csoportban már jelentősebb a területi dekoncentráció (2. ábra). Csak a Dunántúl legdélebbi - föleg baranyai - részét, a Csepel-Mohácsi-sík vizsgált településeit, valamint a Nyírség északnyugati, $\mathrm{s}$ a vele szomszédos tokaji-hegységi térséget jellemzi a vizsgálati cél szempontjából még elfogadhatónak minősített környezeti állapot. Viszonylag még magasabb a közmüvesitettségi mutató, ugyanakkor alacsony pontértékeket kaptak a hulladékelhelyezés terén.

Az utolsó két kategória 73 települése (2. ábra) mind infrastrukturális, mind természeti környezeti mutatóik alapján - és elsősorban az 5. csoport telepulései - a legrosszabb adottságokkal rendelkeznek. Néhány kivételtỏl eltekintve a hulladékelhelyezés, -kezelés területén is igen súlyos problémát jeleznek a rendkívül alacsony pontértékek. Talán csak a levegöminőségi mutató értékében kisebb a lemaradásuk az elsỏ három csoport településeitöl. Itt is megfigyelhetó azonban, hogy ezen telepulések jobb légállapota csak a nyári, nem fütési félévben jó. A téli időszakban magas a füstgázok és a koromszennyeződés mértéke, hiszen alig néhány település rendelkezik vezetékes gázszolgálttatással, s ezekben is alacsony a hálózatra rákapcsolt lakások aránya. 
Oláh Ferenc : A potenciális városok környezeti állapotának értékelése, minősítése

Tér és Társadalom 10. évf. 1996/2-3. 231-236. p.

TÉT 1996 - 2-3

Magyarországi települések...

235

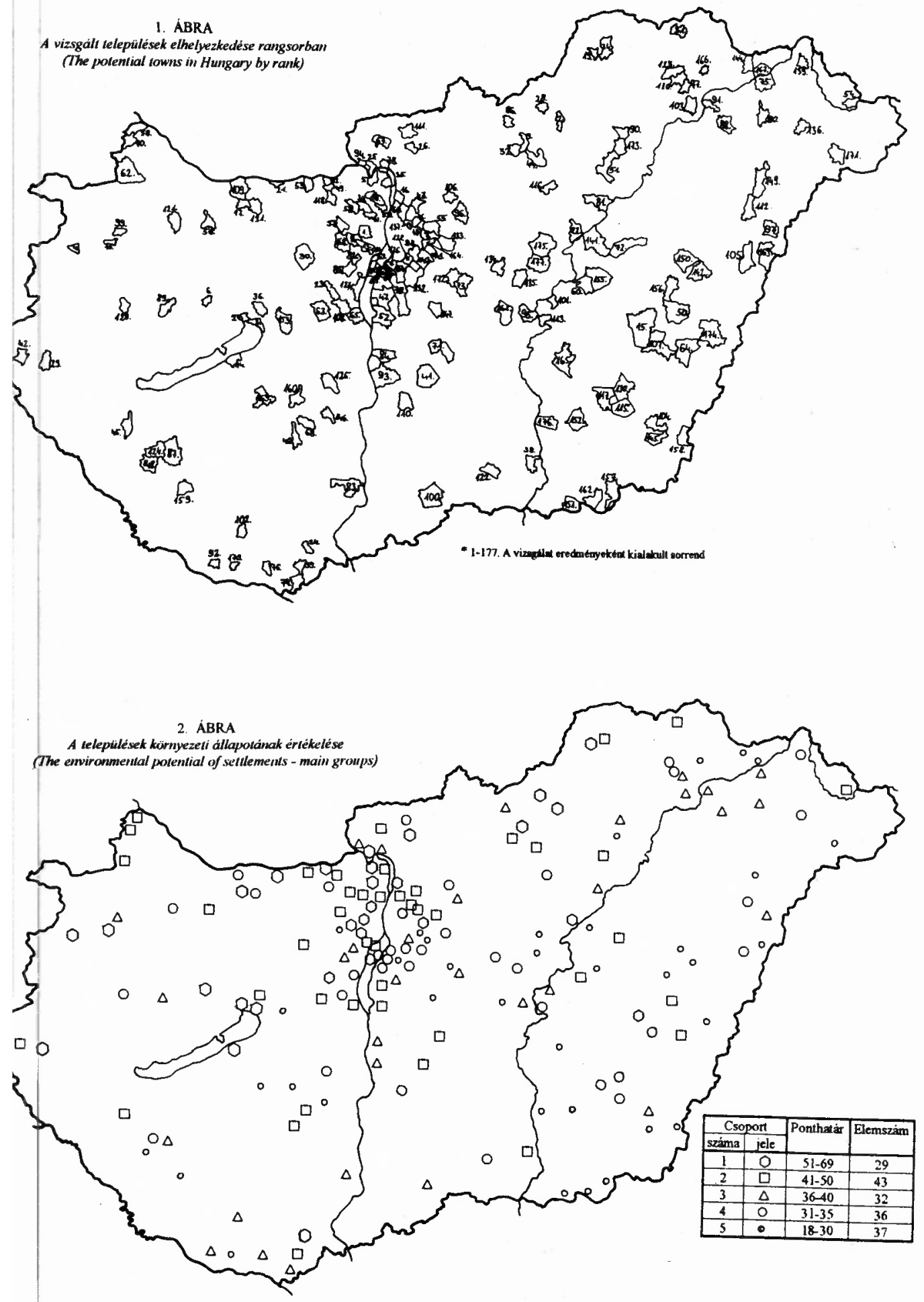


E két csoport településeinek térbeli elrendeződésében megfigyelhető sajátosságok: Az alföldi vizsgált települések döntő többsége, mintegy kétharmada, ide tartozik. A budapesti agglomeráció délkeleti helyzetü települései - néhány kivétellel - szintén itt találhatók. A Dunántúlon a vizsgált Fejér és Somogy megyei települések többsége került e kategóriákba.

\section{Összegzés}

A fenti eredmények hangsúlyozottan csak az aktuális környezeti állapotról tájékoztatnak. Egyes településekre vonatkozóan, egyes vizsgálati szempontok alapadataiban a közeljövöben is történhetnek - reményeink szerint csak pozitív - változások, s ezek következtében a jelenlegitől különbözö is lehet egy-egy település környezeti állapotának megitélése, pozíciója.

Szükség szerint egy-egy települést kiragadva, a jelen vizsgálatban alkalmazott áttekintő jellegủ értékelésnél szélesebb, pontosabb adatbázisra támaszkodva tovább finomitható az értékelési rendszer és az általa mutatott állapot is valósághübb lehet.

A környezet védelméröl rendelkezö 1995. évi LIII. törvény elöírja a Nemzeti Környezetvédelmi Program kidolgozását. A Programnak tartalmaznia kell - számos más eleme mellett - az ország aktuális környezeti állapotának bemutatását, az elérni kívánt állapotot, az ehhez szükséges kutatásokat, konkrét tevékenységeket is.

Jelen munka talán ehhez is szolgáltathat némi támpontot, kiindulási alapot.

\section{Irodalom}

Az 1995. évi LIII. törvény a környezet védelmének általános szabảlyairól, 1995. Budapest. (in. Bándi Gy.: Környezetvédelmi kézikönyv, KJK. 239-288. o.)

Hazánk környezeti állapotának mutatói. 1994. Budapest. KTM. 67 o.

Magyarország Nemzeti Atlasza. 1989. Kartográfiai Vállalat, Budapest. 395 o.

Nemzeti Környezet-és Természetpolitikai Koncepció. 1994. Budapest. KTM. 97. o.

Megyei Statisztikai Évkönyv 1994, 1995. KSH. Megyei Igazgatóságok, 19 megyei kötet

\section{Abstract}

The purpose of a comprehensive research, survey was to carry out the evaluation, qualification and classification of the state of environment in 177 - preliminary selected settlements, for the criterion of comparability, in a numeric way.

We have to emphasise that the findings only inform us about the present state of the environment. In the basic data of some aspects of the survey, in some settlements changes can take place in the near future. As a consequence of this, the perception and position of the state of the environment in an individual settlement can be different from what they are like today.

Focusing on the individual settlements and building on a database which is wider and more precise than the comprehensive evaluation applied in this survey, if necessary, the evaluation system can be further improved and the situation which it reflects can be more accurate. 